UDK: 336.747.6(497.11)

DOI: $10.1515 /$ jcbtp-2017-0011
Nikola Fabris *, Nina Vujanović **

\section{The Impact of Financial Dollarization on Inflation Targeting: Empirical Evidence from Serbia}

\begin{abstract}
Serbia has applied inflation targeting against the backdrop of financial dollarization for almost a decade. In such circumstances, efficiency of monetary policy instruments decreases and begs the question of efficiency of the monetary regime efficiency issue. Although there is some empirical testing of financial dollarization effects on monetary policy performance in the inflation targeting regime for some countries, such studies for Serbia mostly cover periods of early application of the regime.

Therefore, the authors analysed financial dollarization effects on prices, i.e. exchange rate pass-through effect using Serbia as an example. The study concludes that although unpredictable changes in financial dollarization strongly affect nominal exchange rate, prices level is subject to moderate but persistent increase upon this shock.
\end{abstract}

Key words: Serbia, financial dollarization, inflation targeting, passthrough effect.

Jel code: E42 and E52
${ }^{*}$ Faculty of Economics, Belgrade University and Central Bank of Montenegro

E-mail:

nikola.fabris@cbcg.me

${ }^{* *}$ Central Bank of Montenegro

E-mail:

nina.vujanovic@cbcg.me

\title{
Introduction
}

New Zealand was the first country to apply the inflation targeting regime in 1988. Since then, the regime has grown in popularity. Serbia has applied inflation targeting for almost a decade against the backdrop of financial dollarization that significantly reduces efficiency of the instruments in use. 
Dollarization complicates the process of setting monetary policy objectives since monetary policy creators have to include foreign currency into analyses and decision-making adequately. Against the background of lower transaction costs in inflation conditions, dollarization could increase money supply and exchange rate fluctuations. Plata and Herrero (2007) showed that, in the conditions of hyperinflation and economic instability, the share of foreign currency increases and it does not decrease even after inflation trends down.

Financial dollarization brings many challenges that could have adverse effect on pursuing the inflation target (Fabris \& Galić, 2016), such as:

- increased exchange rate "pass-through" effect,

- economy's vulnerabilities to balance sheet channel,

- increased sensitivity to external shocks,

- absence of control of monetary aggregates,

- decreased efficiency of monetary instruments, etc.

Serbia has recorded rather significant results during the application of inflation targeting. It has not reached the inflation target during most of the years (seven out of ten). However, over the past three years, it has fell short somewhat below the target with a significant decrease in the exchange rate fluctuation. Still, a strong influence of the currency rate on meeting inflation target was present during observed period, with rather frequent operations in the exchange rate market during some years. Numerous studies conducted in the beginning of inflation targeting implementation showed high pass-through effect in Serbia (Josifidis et al., 2009; Vilaret, Pješčić \& Djukić 2009).This empirical analysis builds on these finding, investigating how financial dollarization affects the price level in Serbia. The empirical evidence on the effect of financial dollarization on the price level (or inflation) have been recent and scarce (Caranzi et al., 2009; Mengesha et al. 2015). Hence, this study tries to contribute additionally to the understanding of effects of financial dollarization.

\section{Monetary regime in Serbia}

The National Bank of Serbia (NBS) has applied inflation targeting since 2006. It attains the targeted inflation rate by adjusting interest rates on two-week repo operations, which is the main reference rate and key monetary instrument. Other monetary policy instruments, such as issuing long-term securities or reserve requirements, have a supporting role in pursuing the inflation rate. Their objective is to contribute to a smooth transmission of the main reference interest rate. 
In addition, FX reserves should be used rarely and only if other options to affect inflation through the reference interest rate have been exhausted, without setting any numerical values for the exchange rate.

Still, this regime does not exclude the application of interim interventions in the foreign exchange market that may be used primarily for mitigating interim shock effects. However, it is assumed interventions are interim only in case of large shocks, not presuming their continuous presence and central bank's active role in the foreign exchange market. Nevertheless, in the case of Serbia, it may be noted that they were rather frequent in some periods, as shown in Figure 1.

The main difficulty Serbia is facing is the fact that it pursues the inflation targeting regime in the conditions of dual currency regime (financial dollarization). Dual currency system is a typical reaction to economy's instability and high inflation. The literature has not yet come to a consensus on how dual currency systems may affect the pursuit of monetary policy. Takodje, literatura ne pruža ni jasan odgovor oko režima deviznog kursa i monetarnog režima u dovovalutnim sistemima. Moreover, it does not provide a concise answer to foreign exchange and monetary regimes in dual currency systems. Still, there is a common opinion that pursuing monetary policy in dual currency systems is more complicated and less efficient.

The first problem that countries applying this regime face refers to short-term interest rates as an operating instrument. The dilemma is whether the reference interest rate is sufficiently "strong" to affect reduction of inflation expectation, in the conditions of widespread informal euroisation (Fabris, 2006). In dual currency systems, multiple transactions are in foreign currency and domestic shortterm interest rate mostly affects transactions in local currency. This also means that foreign short-term interest rates affect domestic transactions, i.e. a change in domestic interest rates has to compensate for undesired movements of foreign interest rate. In the conditions of growing inflation expectations, this could lead to higher restrictions in monetary policy compared to single currency systems. Moreover, this would require more frequent interest rate changes since they now 
have to compensate for both domestic and foreign adverse shocks. In order to use short-term interest rates as an operational rule successfully, they are required to be stable and predictable, otherwise financial markets would not have a clear benchmark for establishing interest rates in local currency applicable to different maturities. Therefore, in the existence of high inflation and its significant variability, the use of short-term interest rates could bring additional (undesired) variability to a local market.

This also raises a dilemma whether the exchange rate trends have a "stronger" effect on the inflation rate than the reference interest rate. The NBS research in the early days of inflation targeting pointed to a strong effect of the exchange rate. The above mentioned research (Tasić, 2008) estimated the pass-through effect between 0.13 and 0.31 in the short-run, and between 0.19 and 0.50 in the long-run. During depreciation of the domestic currency (against the nominal effective exchange rate constructed from euro and U.S. dollar) the effect is considerably higher, and it reaches even 0.90 when we look at the retail price index. Later NBS researches also showed strong exchange rate depreciation effect on price movements in Serbia in the short-run as well. The exchange rate shock effect on domestic prices lasts over one year, but it is mostly present during the first three months. Practically two thirds of total transmission effects are noticeable in prices during the first three months and complete during the year (Milićević, 2012). Josifidis et al. (2009) came to a similar conclusion, when the comparison of three former transition economies with the Serbian case indicated strong and persistent exchange rate pass-through. Petrović and Mladenović (2015) came to a slightly different conclusion, showing that sets of ERPT estimates show that the long-run pass-through was incomplete, i.e. less than 1 , and low.

National currency's depreciation directly affects the movement of prices. This usually starts the following spiral: exchange rate increase $\Rightarrow$ salaries and costs increase $\Rightarrow$ inflation growth $\Rightarrow$ exchange rate growth (Dimitrijević, B. \& Fabris, N., 2009). To wit, imported products become more expensive and affect growth in prices of other products as well, either because they have the import component or because of the mirror effect. However, this effect on price growth is not present in the short term, but it may be monitored over the long term. This means that price movements could deviate from the exchange rate during some years, but these measurements adjust in the long term. The prices of all products containing the import component could remain the same at the expense of trade margin in the short term, but even the possibilities of the margin decrease have their limits in order to prevent losses. 
Table 1 below shows the inflation targets in Serbia. In most of the years, the target was missed; however, although inflation fell short of the target in the past few years, the recorded inflation rate may be assessed as satisfactory, and the exchange rate stability was preserved as well.

Table 1: Meeting the inflation target in Serbia

\begin{tabular}{ccc}
\hline Year & Target inflation (\%) & Recorded inflation (\%) \\
\hline 2006 & $7-9$ & 5.9 \\
\hline 2007 & $4-8$ & 5.4 \\
\hline 2008 & $3-6$ & 10.1 \\
\hline 2009 & $6-10$ & 6.6 \\
\hline 2010 & $4-8$ & 10.3 \\
\hline 2011 & $3-6$ & 7 \\
\hline 2012 & $2.5-5.5$ & 12.2 \\
\hline 2013 & $2.5-5.5$ & 2.2 \\
\hline 2014 & $2.5-5.5$ & 1.7 \\
\hline 2015 & $2.5-5.5$ & 1.5 \\
\hline
\end{tabular}

Source: National Bank of Serbia

\section{Inflation targeting in dual currency regimes}

Countries facing financial dollarization conditions are facing multiple difficulties in pursuing monetary policy. In their study, Felices and Tuesta (2000) showed that macroeconomic volatility grows with higher level of dollarization. They also concluded that the higher the degree of dollarization, the larger the effect of foreign shocks over the aggregate supply and the less effective the central bank is in stabilizing inflation.

Monetary aggregates in dual currency countries are only under central bank's partial control, since a significant portion of money supply is in the relevant foreign country. In such a situation, economic entities affect the money supply structure by choosing between local and foreign currency. Berg and Borenstain (2000) found that monetary aggregates which also cover deposits in foreign currency are most closely connected with inflation. The IMF study (2000) showed that, in such circumstances, money supply might decline considerably (by changing currency) in short term if economic policy's credibility decreased. 
In the situation of low currency substitution costs, the exchange rate depreciations may lead to change in money demand and accelerated velocity of money circulation. If the change originates from local currency depreciation, economic entities will make effort to "get rid of it" by substituting it with foreign currency or use it for purchase. Thus the change in money demand leads to accelerated money circulation velocity which aggravates the pursuing of inflation target.

Another difficulty these countries face is the fact that exchange rate fluctuations pose a significant risk to pursuing inflation target and may lead to financial stability aggravating. This problem may be particularly pronounced in countries with high "pass-through" effect. In such conditions, non-tradable goods are also bound to foreign currency. Thus, exchange rate changes reflecton numerous products and services. Plata and Herrero (2007) noted that in countries with high degree of dollarization, prices largely react to changes in the exchange rate. Similar conclusion was made by Reinhart et al. (2003), i.e. that the "pass-through" effect is much higher and more persistent in highly dollarized economies. Using the example of Latin America countries, Calvo and Veigh (1992) showed the existence of strong positive correlation between the substitution of currencies and the exchange rate volatility. These studies unambiguously conclude that exchange rate changes lead to changed prices and that this could be the aggravating factor for the pursuing of inflation target.

Coulibaly and Kempf (2009) showed that inflation targeting in emerging countries appears to decrease exchange rate pass-through to various prices (import prices, producer prices, and consumer prices). However, their study did not dispute the existence of high pass-through effect in countries with financial dollarization.

Both public and private sectors of developing countries often borrow in foreign currency, increasing country's vulnerability to external shocks. Since their revenues are in local currency, this means that local currency depreciation increases debt repayment burden. Depreciation may be extremely dangerous if loans granted in foreign currency are used for investing in underdeveloped sectors since significant exchange rate fluctuations may then lead to a balance of payment crisis.

Depreciation may lead to deterioration of a country's financial stability. To wit, receivables and loans in many emerging countries are in foreign currency, while revenues are in local currency. In the situation of local currency depreciation, the burden of repaying liabilities in foreign currency grows, which may result in some economic entities being unable to settle their obligations, which leads to 
growing non-performing loans in the banking system and aggravated financial stability.

In the situation when there are significant changes in prices and exchange rate, central bank needs to intervene with a view to maintaining the inflation target. However, frequent foreign exchange market interventions deviate from one of the primary assumptions of inflation targeting, this being freely floating exchange rate. Many authors highlight that interventions in the foreign exchange market do not conflict inflation targeting regime although theory suggests otherwise. Leiderman et al. (2006) showed that interventions in the foreign exchange market support inflation targeting.

This may lead to the conclusion that countries with lower share of dollarization and lower "pass-through" effect may pursue inflation targeting regime more efficiently. As Armasi-Grippa (2005) noted, low exchange rate "pass-through" effect was the key reason for Peru's success in inflation targeting despite the presence of dollarization. Israel is an example of a country that managed to decrease the share of parallel currency after introducing inflation targeting, which contributed to the success of the regime. This hypothesis was confirmed and investigated by Nojković and Petrović (2015) who determined, using the example of European emerging economies using inflation targeting, that the level of euroisation measured by the share of deposits and loans in foreign currency affects whether the exchange rate should be treated as a separate objective.

Many studies have shown that countries using the inflation targeting regime lead active exchange rate policy (Nojković \& Petrović 2015, Fabris, J. 2015, Leiderman et al. 2013, Edwards 2006, Mohanty \& Klau 2004, etc.). Therefore, it is obvious that central banks in emerging economies could make an effort to stabilize the exchange rate independently of inflation target, provided that their trends are compatible. On the other hand, Mishkin (2000) opposes excessive interventions in the foreign exchange market of emerging economies with inflation targeting regime, believing that they transferred the exchange rate into nominal anchor that takes precedence over the inflation target.

However, numerous studies pointed that inflation targeting is possible even in the conditions of financial dollarization. Leiderman et al. (2006) conclude that despite the fact that dual currency regime affects transmission mechanism differently, the option of these countries' using inflation targeting should not be excluded. Batini, Leavine and Pearlman (2008) made a similar conclusion that pursuing monetary policy in dual currency systems may be challenging but also successful in inflation targeting regime. 


\section{Data}

For the purpose of empirical investigation, the authors used data on the level of financial dollarization (FD) measured as the percentage of foreign deposits in total corporate and household deposits, the indirect quote nominal Dinar/Euro exchange rate $(\mathrm{EXCH})$ (i.e. upward movement signifies depreciation of the Dinar), and the consumer price index (CPI) as our representative price level. ${ }^{1}$ The authors used quarterly data, to be consistent with the relevant empirical literature, which largely relies on quarterly aggregate data (Plate and Herrero, 2007; Ca'Zorzi et al., 2007; Mengesha et al., 2015). The period under study covers 2006Q1 to 2016Q1

Figure 2: CPI index, inflation, exchange rate, and percentage of foreign deposit

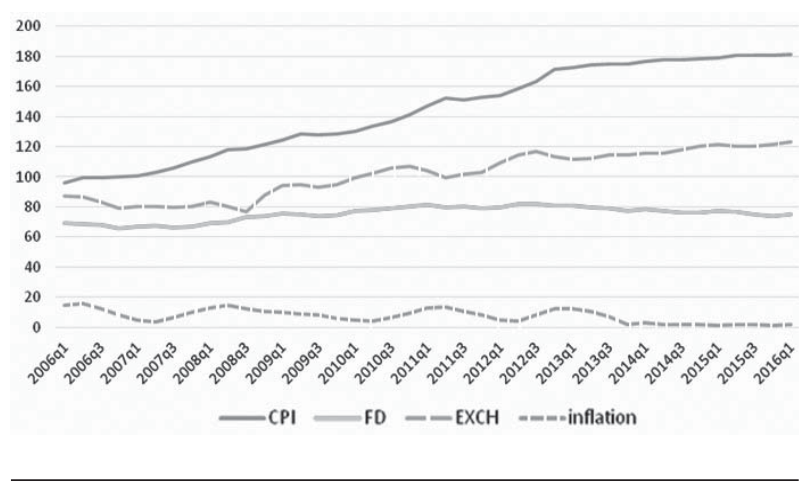

Source: National Bank of Serbia, Statistical Office of the Republic of Serbia and corresponds to the period during which inflation targeting was used as the monetary policy regime in Serbia. During that period, Serbia was an independent country (before May 2006, Serbia was a republic within the State Union of Serbia and Montenegro), which further justifies the usage of this timeframe. Figure 2 shows the level of quarterly series used in the study together with the rate of inflation (yearon-year CPI percentage change).

As can be seen from Figure 2, FD in Serbia is quite high, reflecting experiences in the early 1990s during/after the break-up of Yugoslavia. During 1989-1994, the budget deficit in ex-Yugoslavia was financed by printing money, which led to the highest hyperinflation in the world. Due to the dramatic weakening of the purchasing power of domestic currency, Dinar, households and the corporate sector lost their savings and trust in the banking sector. Ever since, foreign currency circulation in Serbia has been strongly present (first German marks, then Euro) due to mistrust in the Dinar. Hence, Serbia has had a high level of dollariza-

\footnotetext{
1 Quarterly data are calculated as the average of the series monthly levels.
} 
tion throughout the inflation targeting period. During the ten-year period under study, financial dollarization ranged from $65.8 \%$ in $2006 \mathrm{Q} 4$ to $81.9 \%$ in $2012 \mathrm{Q} 3$, while its mean value was around $75 \%$.

The Euro/Dinar exchange rate effects on prices could proxy for the total exchange rate pass-through (ERPT), considering that the main trading partners in Serbia use the euro as their official currency (40.8\% of total import in 2012; source: Serbian Statistical Office). Taylor (2000) hypothesizes that if exchange rate fluctuations are temporary then ERPT is also low. Changes in the exchange rate movements in Serbia, however, do not seem to have been temporary. On the contrary, the exchange rate continuously depreciated during the studied period and ranged from 76.7 in 2008Q3 to 123.2 in 2016Q1. ${ }^{2}$

Similarly, Taylor (2000) hypothesizes - in accordance with purchasing power parity - that the domestic currency depreciation is higher in countries with high inflation (other factors held constant). During the studied period, inflation averaged $7.4 \%$, while the minimum and maximum were $0.9 \%$ (2015Q1) and $15.6 \%$ (2016Q2), respectively. Serbia could be considered a country of high inflation. However, inflation during the studied period has had a downward sloping trend. Indeed, during 2013Q4-2016Q1, inflation was below the targeted band, mostly due to globally low primary commodity prices (food and oil) and subdued aggregated demand domestically (NBS, 2014; 2015). The Figure above also shows that the nominal exchange rate index and the CPI index follow roughly the same upward trend. This is also confirmed by the Johansen cointegration test, justifying the relationship implied by absolute purchasing power parity (PPP).

Summary statistics of financial dollarization, the exchange rate, the price level, and inflation in Serbia are presented in Table 2. The table presents the number of studied periods (quarters) together with the mean, standard deviation, and minimum and maximum of each variable.

2 The Euro-Dinar exchange rate depreciation was notable ever since the formation of the Economic and Monetary Union. In January 2002 and March 2016, the EXCH rate was 59.9 and 123.3 , respectively. 
Table 2: Summary statistics: $\%$ of foreign deposits, exchange rate, CPI index, inflation

\begin{tabular}{lccccc}
\hline Variable & Obs & Mean & Std. Dev. & Min & Max \\
\hline FD & 41 & 75.26667 & 4.880195 & 65.80334 & 81.94334 \\
\hdashline EXCH & 41 & 101.5919 & 15.09428 & 76.67667 & 123.375 \\
\hline CPI & 41 & 143.8655 & 29.65663 & 96.01853 & 181.5493 \\
\hdashline INFLATION & 41 & 7.396667 & 4.461863 & .9333333 & 15.59 \\
\hline
\end{tabular}

\section{Methodology and results}

The methodology applied is a Vector Autoregressive (VAR) model, which takes into account the endogeneity of variables and enables the investigation of how a shock to one variable transmits through the VAR system. The VAR system is presented in a vector form in (1):

$$
Y_{t}=c+\sum_{i=1}^{p} \phi_{i} Y_{t-1}+\varepsilon_{t}
$$

where $\mathrm{Y}_{\mathrm{t}}$ represent the vector of three endogenous variables $\mathrm{FD}, \mathrm{EXCH}$ and $\mathrm{CPI}$, $c$ is the vector of equation specific constants, while $\varepsilon_{t}$ is the vector of the error terms, or innovation (shocks) to the three variables. All the variables are in logarithm. Unit root tests indicated the non-stationarity of the variables while the Engle-Granger cointegration tests confirm that EXCH and CPI series are cointegrated. There are arguments for both, estimation of VAR with series in difference and in level form. Sims (1980) and Sims et al. (1990) validated the inclusion of level variables as VAR should replicate the true data-generating process. However, in the presence of cointegration, Marcet et al. (2004) argue that VAR could suffer from over-parameterisation and efficiency loss. Furthermore, using VARs in levels requires more restrictive assumptions than that of VAR in difference. His paper shows that VAR with level variables do not uncover true innovation and that time-differencing is desirable even in the presence of series' stationarity.

Considering the presence of cointegration, the viable methodology could be vector error correction model (VECM) which takes into account the cointegration of endogenous variables and measures their long- and short-run equilibrium adjustment. However, the time span of the series is rather short (forty quarterly observations). Additionally, the purpose of this analysis is the effects from short term shocks in financial dollarization. Thus, keeping in mind the critique by Marcet (2004) and the purpose of this empirical analysis, we decided to base our strategy on VAR with differenced variables. 
Structural shocks are identified with Cholesky decomposition of variance-covariance matrix of the reduced form residuals $\varepsilon$ and the causal ordering of variables in the system (Sims, 1980), Hence, the order of the equations is important because the shock in one variable first affects the variable ordered consecutively after the variable exposed to a shock. The shock then transmits to the following variables. However, the second variable should not subsequently affect first variable, and a change in the third variable should not subsequently alter changes in variable ordered as first and second in the system. The direction of instantaneous causation comes from the economic theory (Lutkepohl, 2005). The price level is affected by the exchange rate, though imported goods and services that directly cause inflation. Likewise, dollarization is caused by greater inflation (Reinhart et al., 2003), as explained in section one. The level of dollarization could increase the price level, through the ERPT mechanism. However, later effects are less likely to be contemporaneous. This justifies the order of EXCH, CPI and FD being the first, second, and third in the system, respectively.

Series are seasonally adjusted to take into account seasonal patterns. Two time dummies are included to account for changes in the respective definitions of CPI index and foreign deposits. Until July 2008, foreign deposits present predicted values of the National Bank of Serbia (NBS). In addition, the CPI index has a different definition from January 2007 onwards. Hence, two time-dummies are included, $\mathrm{d} 1$ being one from 2007 onwards and $\mathrm{d} 2$ taking the value one from 2008Q3 onwards. Various information criteria - Akaike's, the Schwarz's Bayesian and the Hannan and Quinn - all indicated that the vector autoregression should be of the order one and two. The results of the model are presented in Table 3. First, second and third column represent the three equations in the VAR model in the order they appear, with their respective independent variables at lag one $(-1)$ and two (-2) presented in rows. The diagnostic tests, available in the appendix show that the model is stable (eigenvalues are lower than one), and that the VAR model does not suffer from autocorrelation of the error terms at various lags. 
Table 3: Results from estimating VAR presented in (1)

\begin{tabular}{lrrr}
\hline & EXCH & CPI & FD \\
\hline EXCH (-1) & 0.185 & $0.069^{*}$ & 0.139 \\
& $(0.172)$ & $(0.051)$ & $0.114)$ \\
\hline EXCH $(-2)$ & $-0.219^{*}$ & 0.059 & -0.100 \\
& $(0.155)$ & $(0.053)$ & $(0.103)$ \\
\hline CPI (-1) & $-0.909^{*}$ & $0.318^{* *}$ & 0.201 \\
& $(0.500)$ & $(0.173)$ & $(0.332)$ \\
\hline CPI $(-2)$ & -0.021 & -0.050 & 0.018 \\
& $(0.425)$ & $(0.147)$ & $(0.283)$ \\
FD $(-1)$ & $0.927^{* * *}$ & $0.297^{* * *}$ & 0.210 \\
& $(0.270)$ & $(0.093)$ & $(0.180)$ \\
\hline FD $(-2)$ & 0.085 & $0.169^{*}$ & -0.053 \\
& $(0.350)$ & $(0.121)$ & $(0.233)$ \\
\hline C & -0.031 & $0.004^{* *}$ & -0.027 \\
& $(0.025)$ & $(0.009)$ & $(0.017)$ \\
D1 & $0.049^{* *}$ & $0.017^{* * *}$ & $0.029^{* *}$ \\
& $(0.027)$ & $(0.009)$ & $(0.018)$ \\
\hline D2 & 0.007 & -0.014 & $-0.004^{*}$ \\
& $(0.012)$ & $(0.004)$ & $(0.008)$ \\
\hline
\end{tabular}

Log likelihood

Akaike information criterion -16.224

Schwarz criterion $\quad-15.060$

Note: ${ }^{*} p<0.05,{ }^{* *} p<0.01,{ }^{* * *} p<0.001$. se are in parenthesis.

FD affects the price level in a twofold manner, directly and indirectly. The results show that FD seems to have a direct positive effect on prices. Indirect effect occurs through ERPT. In fact, EXCH has a significant positive effect on the price level, implying the evident presence of the ERPT mechanism in Serbia. FD, on the other side, has a strong positive effect on the exchange rate. Hence, FD, as influential factor of the exchange rate, could prompt further price increase, through ERPT. Of all three variables, only price levels show a high level of time persistence (rigidity). Generally, it is difficult to infer conclusions from examining the coefficient only as the VAR system accounts for the interrelation among variables rather than the parameter estimates (Sims, 1980; Enders, 2015).

The Granger-causality test reveals that financial dollarization seems to cause both the exchange rate and prices. The opposite does not hold - prices and exchange rate do not cause financial dollarization. This effect is somewhat unexpected and could be assigned to the period under study, during which financial dollarization in Serbia is rather stable, no matter the inflation. Due to high financial dollarization accruing after hyperinflation and economic instabilities from the 1990s, FD could be viewed as a predetermined condition during the period under investigation. 
The importance of the VAR system comes primarily from the impulse response function (IRF). The impulse response function (IRF) is performed using Cholesky decomposition. The shock comes from the error term related to financial dollarization equation in the VAR system in (1). Figure 3 shows how a one-standard deviation shock in one variable affects the variables in the system throughout ten quarters (x-axis). Shock (unexpected change) in FD occurs in the first quarter, affecting the $\mathrm{EXCH}$ and $\mathrm{CPI}$ in the later quarters: dlnexch_sa, dlncpi, dlnfd_sa represent differenced, seasonally adjusted exchange rate, CPI index, and financial dollarization, respectively. The Figure shows how the variable exposed to a shock (first variable name above each graph presented in the Figure) influences the variable in the VAR system (second variable name).

It could be seen that the shock in financial dollarization positively and strongly affects the changes in the exchange rate, particularly in the second quarter after the shock occurred. Variance decomposition reveals that $24.6 \%$ to $28.3 \%$ of the forecast error of the variance of the exchange rate from the second to the tenth quarter is explained by the shock in the financial dollarization. This increases the scope of the possible effects on the price level through the ERPT. However, the ERPT seems to be moderate. The variation in the price level moderately reacts to shock in the exchange rate. In the first and second quarter, $2.3 \%$ of the forecast error variation in the price level is explained by the shock in the exchange rate. The variation due to this shock, however, increases to $11-12 \%$ for the third quarter onwards, implying the increasing effect of
Figure 3: IRF performed after the VAR estimation

Response to Cholesky One S.D. Innovations $\pm 2 S$. E Response of DLNEXC_SA to DLNFD_SA

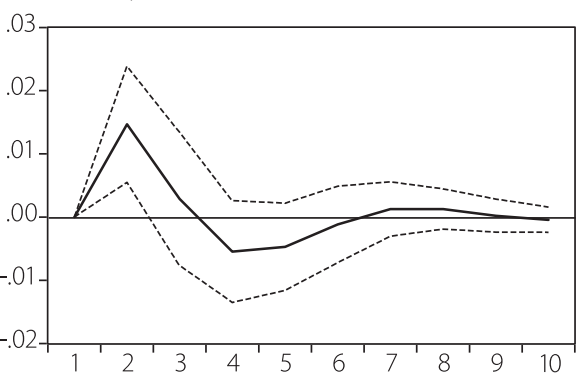

Response of DLNCPI_SA to DLNFD_SA

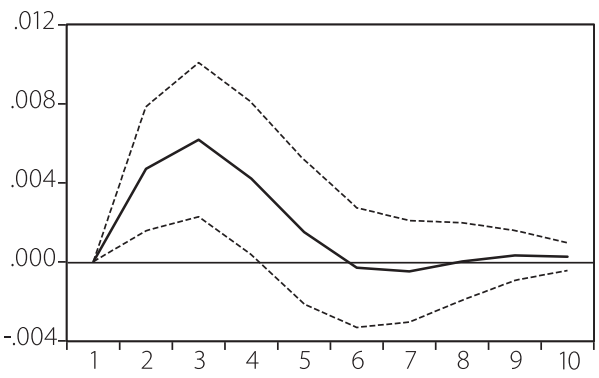

Response of DLNFD_SA to DLNFD_SA

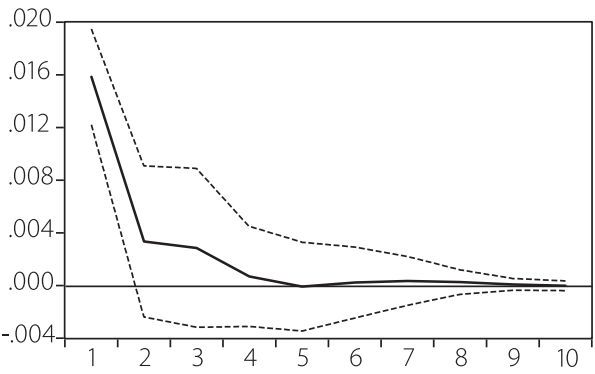


ERPT in the later periods. The variation in the price level seems to be accruing more and increasingly from the direct shocks in the FD. In the second quarter, $21 \%$ of the variation of the forecast error of the price level is explained by the shock in the FD. The explanatory power of FD shock on the prices increases to $38.4 \%$ in quarter three and $44 \%$ in later quarters.

Considering that variable differencing could reduce some variability, caused by the co-movements with other variables (Enders, 2015), the VAR is further estimated with level variables, keeping in mind the possible issue of misspecification due to cointegration (Marcet, 2004). The inclusion of variables in levels also simplifies the interpretation, giving it a more economic meaning. This is because FD is expressed in percentage points, while EXCH and CPI are in logarithm. The results (available upon request) show that the shock in FD causes only benign but persistent effects on inflation. In fact, 1p.p increase in FD leads to only $0.01 \%$ increase in CPI index. The forecast error variation of the prices is increasingly explained by the exchange rate shock (6.3\% in quarter two to $19.2 \%$ in quarter ten) and the shock in the financial dollarization (11\% in quarter two to $33 \%$ in quarter ten), the latter having a stronger effect.

As explained earlier, FD could affect prices directly and indirectly, through ERPT. A positive effect is in line with the findings of positive effect on inflation from financial dollarization (Caranzzi et al., 2009; Mengesha et al., 2015). A moderate effect on prices could be explained with possible benign effect of ERPT in Serbia. Earlier studies on the ERPT (Tasic, 2008; Josifidis et al., 2009) find a strong ERPT in Serbia. However, Tasic (2008) and Josifidis et al. (2009) rely on monthly data and their sample periods cover the period when prices were progressively liberalized and largely administratively controlled (Tasic, 2008), as well as to the time span encompassing the period of hyperinflation in Serbia (Josifidis et al., 2009).

On the contrary, a later study finds that ERPT in Serbia is decreasing over time. In fact, Petrovic and Mladenovic (2015) find that in Serbia ERPT decreases as inflation decreases, pointing to a moderating ERPT over time (1992-2000). As earlier explained, inflation during the studied period was decreasing, fluctuating around 2\% from 2013Q4 onwards. Carranza et al. (2009) also find that dollarization plays a role on ERPT, but that the effects are non-linear. They find that ERPT is hampered in highly dollarized economies if exchange rate depreciations are high (which they are in Serbia). Possibly moderate ERPT could be also explained with inflation targeting regime employed and frequent NBS operations in the foreign exchange rate market during the period under study, which could lower the indirect effect of FD on price levels, through ERPT. 
For robustness check (available upon request), the authors undertook series adjustment to account for the change in the definition of FD and CPI variables by regressing time-dummies on the series and using the residual of this regression as the new adjusted series. Then, the VAR model is estimated with this residual series. The results remain robust. Furthermore, the authors altered the order of the variables in the system. Due to stable levels of FD in the period under study and its predetermined condition, we assumed that there are no contemporaneous effects from the exchange rate and price level on further financial dollarization. Considering its relatively stable and enduring presence in Serbia, FD could continuously affect the price level while subject to only subsequent feedback from the price level. Hence, we placed FD variable as first in the system, followed by EXCH and CPI. The results remain robust.

\section{Summary and conclusion}

Serbia has been applying inflation targeting regime since 2006. The regime is being applied in the conditions of widely spread financial dollarization. Against this backdrop, the increased currency rate pass-through effect aggravates the application of the regime resulting from lower efficiency of monetary policy instruments and increased sensitivity to external shocks.

The study contributes to the literature by investigating the effects of financial dollarization on the price level in Serbia, a topic with scarce and only recent evidence. The period under study corresponds to the period of inflation targeting in Serbia. Hence, the study gives a better insight of this phenomenon during the period when the central bank controls prices more directly. Furthermore, unlike the previous studies on financial dollarization in Serbia that use monthly data, this study relies on quarterly data, enriching the evidence of financial dollarization with different levels of data aggregation.

The findings show that the effect from the financial dollarization shock on the exchange rate is strong. Some $24.6 \%$ to $28.3 \%$ of variation in the forecast error of the exchange rate during the second to the tenth quarter is explained by the shock in the financial dollarization. Surprisingly, the overall effect on prices from the shock on financial dollarization is low, but persistent. These effects are most prominent in the second, third, and fourth quarter after the shock occurs and they diminish in the fifth quarter. The long-lasting effects could apply to price rigidities, also detected in the results from VAR model, while low effects could result from the low exchange rate pass-through mechanism. The effects on prices, upon the shock in FD, comes mostly from the direct effect from the financial dol- 
larization itself, rather than the ERPT. During the time span of two and a half years, $2.3 \%$ to $12 \%$ of variation of the forecast error in the prices is explained by the shock in the exchange rate. On the other hand, $21 \%$ to $44 \%$ of the the forecast error variance in the price is explained by the shock in financial dollarization.

In fact, the recent empirical literature on the exchange rate pass-through on prices shows decreasing effects from this mechanism in countries with high dollarization but large exchange rate depreciations and in countries with decreasing inflation. As the both phenomenon have been present in Serbia during the period under study, they could partially explain why the effects from the shock in financial dollarization on prices are moderate. Additionally, we study the period when inflation targeting was adopted as monetary policy, but also the period of the NBS frequent operations in the exchange rate market. Inflation targeting might have contributed to price stability in Serbia, while the exchange rate market operations could have controlled the effects from external shocks on the price level. Both facts could lower the exchange rate pass-through. A more direct inference, however, calls for further research in future, possibly with longer time series. 


\section{References}

1. Armas, A. \& Grippa, F. (2005), Targeting Inflation in a Dollarized Economy: The Peruvian Experience (Banco Central de Reserva del Peru, Working Paper 538), Lima: Banco Central de Reserva del Peru.

2. Batini, N., Levine, P. \& Pearlman J. (2008). Optimal Exchange Rate Stabilization in a Dollarized Economy with Inflation Targets (Banco Central de Reserva del Peru, Working Paper 004), Lima: Banco Central de Reserva del Peru.

3. Berg, A. \& Borensztein, E. (2000). The Choice of Exchange Rate Regime and Monetary Target in Dollarized Economies (International Monetary Fund Working Paper 00/29), Washington: IMF.

4. Calvo, G. \& Vegh, C. (1992). Currency Substitution in Developing Countries: An Introduction. Revista de Análisis Económico-Economic Analysis Review, 7 (1), pp. 3-27.

5. Carranza, L., Galdon-Sanchez, J. E., \& Gomez-Biscarri, J. (2009). Exchange rate and inflation dynamics in dollarized economies. Journal of Development Economics, 89(1), pp. 98-108.

6. Ca' Zorzi, M., Hahn, E., \& Sánchez, M. (2007). Exchange rate pass-through in emerging markets (European Central Bank Working Paper 739), Frankfurt: ECB.

7. Coulibaly, D. \& Kempf, H. (2009). Does Inflation Targeting Decrease Exchange Rate Pass- through in Emerging Countries? Retrieved from https:// www.gate.cnrs.fr/IMG/pdf/Coulibaly_2011.pdf

8. Enders, W. (2015). Applied Econometrics Time Series (Fourth Edi.).

9. Dimitrijević, B. \& Fabris, N. Makroekonomija. (2009). Educons University, Novi Sad.

10. Edwards, S. (2006). The Relationship Between Exchange Rates and Inflation Targeting Revisited (NBER Working Paper 12163), Cambridge: NBER.

11. Fabris, J. (2015). Inflation Targeting in Serbia. Journal of Central Banking Theory and Practice, 4(2), pp. 59-74.

12. Fabris, N. (2006). Inflation Targeting With Special Review on Appliction in Serbia. Panoeconomicus, 53(4), pp. 389-405.

13. Fabris, N. \& Galić, J. (2016). Ciljanje inflacije u zemljama sa dvovalutnim režimima. Meeting of Scientific Association of Economists, December. Belgrade: Scientific Association of Economists.

14. Felices, G, \& Tuesta, V. ( 2013). Monetary policy in a dual currency environment. Applied Economics 45(34), pp. 4739-4753.

15. IMF (2000).World Economic Outlook".Washington: IMF. 
16. Josifidis, K. ,Allegret, J. P. \& Beker E. (2009). Monetary and Exchange Rate Regimes Changes: The Cases of Poland, Czech Republic, Slovakia and Republic of Serbia. Panoeconomicus, 58(2), pp. 199-226.

17. Kabashi, R. (2015). Cyclicality, determinants and macroeconomic effects of fiscal policy in European countries, with particular reference to transition countries (Doctoral dissertation, Staffordshire University).

18. Leiderman, L., Maino, R. \& Parrado, E. (2006). Inflation Targeting in Dollarized Economies (International Monetary Fund Working Paper 06/157), Washington: IMF.

19. Lütkepohl, H., (2005). New introduction to multiple time series analysis. Springer Science \& Business Media.

20. Mengesha, L. G. \& Holmes, M. J. (2015). Does dollarization reduce or produce inflation?. Journal of Economic Studies, 42(3), pp. 358-376.

21. Milićević, D. (2012). Devizni kurs - Damoklov mač. Retrived from http://www.makroekonomija.org/0- dragovan-milicevic/devizni-kurs\%E2\%80\%93-damoklov-mac/.

22. Mischkin, F. S. (2000). Inflation targeting in Emerging Market Countries (NBER Working Paper 7618), Cambridge: NBER.

23. Marcet, A. (2005). Over differencing VARs is OK. Manuscript, Universitat Pompeu Fabra. Retrieved from ftp://ftp.cemfi.es/pdf/papers/seminar/marp. pdf.

24. Mohanty, M. S. \& Klau, M. (2004). Monetary Policy Rules in Emerging Market Economies: Issues and Evidence (BIS Working Paper 149), Basel: BIS.

25. National Bank of Serbia. (2016). Inflation Report (February). Belgrade: NBS.

26. National Bank of Serbia. (2014). Annual monetary Policy Report 2014. Belgrade: NBS.

27. National Bank of Serbia. (2015). Semi-annual Monetary Policy Report (January-June 2015). Belgrade: NBS.

28. Nojković, A \& Petrović, P. (2015). Monetary Policy Rule in Inflation targeting Emerging European Countries: a Discrete Choice Approach. Journal of Policy Modelling, 37(4) pp. 577-595.

29. Petrović, P. \& Mladenović, Z. (2015). Exchange Rate Pass-Through and the Frequency of Price Adjustment across Different Inflation Regimes. Panoeconomicus 62(4), pp. 409-427.

30. Plata, A. P. \& Herrero, A. G. (2007). To Dollarize or De-dollarize: Consequences for Monetary Policy", Retrieved from http://www.bis.org/ repofficepubl/arpresearch200709.1.pdf

31. Reinhart, C., Rogoff, K. S. \& Savastano, M. A. (2003). Addicted to Dollars" (NBER Working Paper 10015), Cambridge: NBER. 
32. Sims, C. A., Stock, J. H., \& Watson, M. W. (1990). Inference in linear time series models with some unit roots. Econometrica: Journal of the Econometric Society, 113-144.

33. Tasić, N. (2008). Pass-Through of Exchange Rates to Prices in Serbia: 20012007 (National Bank of Serbia Working Paper no 10), Belgrade: National Bank of Serbia.

34. Taylor, J. B. (2000). Low inflation, pass-through, and the pricing power of firms. European economic review, 44(7), pp. 1389-1408.

35. Vilaret, S., Pješčić, V. \& Djukić, M. (2009).Osnovne karakteristike i dosadašnje iskustvo srbije u sprovođenju strategije ciljanja Inflacije. Retrieved from http://www.ubs- asb.com/Portals/0/Casopis/2009/5_6/B05-06-2009Vilaret-Pjescic-Djukic.pdf. 


\section{Appendix}

Table 4: VAR stability test

Eigenvalue stability condition

\begin{tabular}{cccc}
\hline \multicolumn{2}{c}{ Eigenvalue } & Modulus \\
\hline .3211788 & + & $.5761511 i$ & .659626 \\
.3211788 & - & $.5761511 i$ & .659626 \\
.5188826 & & & .518883 \\
-.227186 & + & $.2740432 i$ & .355968 \\
-.2271862 & - & $.2740432 i$ & .355968 \\
.0069049 & & .006905 \\
\hline
\end{tabular}

All the eigenvalues lie inside the unit circle.

VAR satisfies stability condition.

Table 5: VAR autocorrelation test

Lagrange-multiplier test

\begin{tabular}{crrr}
\hline lag & chi2 & df & Prob > chi2 \\
\hline 1 & 23.1770 & 9 & 0.05810 \\
2 & 7.5285 & 9 & 0.58227 \\
3 & 4.3588 & 9 & 0.88625 \\
4 & 3.8697 & 9 & 0.91978 \\
\hline
\end{tabular}

Table 6: Granger causality test

Granger causality Wald tests

\begin{tabular}{crrrr}
\hline Equation & Excluded & chi2 & df & Prob > chi2 \\
\hline d.Inexc & d.Incpi & 5.4655 & 2 & 0.065 \\
d.Inexc & d.f_dep & 13.842 & 2 & 0.001 \\
d.Inexc & ALL & 17.088 & 4 & 0.002 \\
d.Incpi & d.Inexc & 4.0141 & 2 & 0.134 \\
d.Incpi & d.f_dep & 16.892 & 2 & 0.000 \\
d.Incpi & ALL & 32.463 & 4 & 0.000 \\
d.f_dep & d.exc & 2.9512 & 2 & 0.229 \\
d.f_dep & d.cpi & .63641 & 2 & 0.727 \\
d.f_dep & ALL & 3.0279 & 4 & 0.553 \\
\hline
\end{tabular}




\section{Table 7: Engle-Granger cointegration test}

Sample (adjusted): 2006Q1 2016Q1

Included observations: 41 after adjustments

Null hypothesis: Series are not cointegrated

Cointegrating equation deterministics: $C$

Automatic lags specification based on Schwarz criterion (maxlag=9)

\begin{tabular}{lrrrr}
\hline \multicolumn{1}{c}{ Dependent } & tau-statistic & Prob.* $^{*}$ & z-statistic & Prob.* $^{*}$ \\
\hline LNEXC & -4.042579 & 0.0144 & -28.79345 & 0.0015 \\
LNCPI & -4.272078 & 0.0082 & -27.81837 & 0.0022 \\
\hline
\end{tabular}

*MacKinnon (1996) p-values. 